\title{
Türk Şirket Birleşmelerinin Satın Alınan Şirketlerin Hisse Senedi Fiyatları Üzerindeki Etkileri
}

\author{
Mert Hakan Hekimoğlu \\ Başak Tanyeri*
}

\section{Özet}

Bu çalışmada, Türkiye'de 1991 ile 2009 yılları arasında halka duyurulan birleşmelerin ve kısmi satışların hedef şirket hisse senedi fiyatları üzerindeki etkileri incelenmiştir. Hedef şirket hissedarları, halka duyuru gününü merkez alan üç günlük zaman aralığında, birleşmelerde yüzde 8,56, kısmi satışlarda ise yüzde 2,25 oranında kümülatif anormal getiri elde etmiştir. Bulgular, alıcı şirketlerin, hedef şirket yönetimini ele geçirdikleri birleşmelerde, kısmi satışlara göre daha yüksek bir bedel ödediğini göstermektedir. Hedef şirket hissedarlarının ABD'de (yüzde 20 civarı) ve Avrupa'da (yüzde 10 civarı) görülen kümülatif anormal getirilere kıyasla, Türkiye'de daha düşük getiri elde etmesi iki etkenle açıklanabilir: 1) duyuru tarihini belirlemedeki zorluklar ve birleşme ile ilgili sızan bilgiler; 2) Türkiye'deki yasal düzenlemelerdeki ve rekabet ortamındaki farklılıklar.

Anahtar kelimeler: Türk şirket birleşmeleri, kısmi satışlar

\section{Stock-Market Reactions to Mergers of Non-Financial Turkish Firms}

\begin{abstract}
This paper investigates stock-market reactions to mergers and partial sales of non-financial Turkish firms. Turkish targets earn average cumulative abnormal returns (CAR) of 8.56 percent in the three-day window around merger announcements when bidders purchase control rights and 2.25 percent when they do not. The results indicate that acquirers pay a premium to purchase control rights. The smaller magnitude of target CAR in Turkish mergers (relative to CAR of around 20 percent in US and 10 percent in Europe) may be explained by: 1) the reduction in the power of event study method to capture the effect of merger announcements due to information leakages and misidentification of announcement dates; and 2) the differences in Turkish regulatory, operational and competitive environment.
\end{abstract}

Keywords: Turkish mergers, acquistions, partial sales

JEL: G34, G15

* Mert Hakan Hekimoğlu, Bilkent Üniversitesi'nde doktora öğrencisi olarak çalışmaktadır. Tel: (90) 312-290-1778; e-posta: mhekim@bilkent.edu.tr.

Başak Tanyeri, Bilkent Üniversitesi’nde yardımcı doçent olarak çalışmaktadır. Tel: (90) 312290-1871; e-posta: basak@bilkent.edu.tr. Başak Tanyeri makale yazımı sırasında TÜBİTAK (110K330 projesi) desteğinden yararlanmıştır. 


\section{Giriş}

Bu çalışmada, Türkiye'de 1991 ile 2009 yılları arasında halka duyurulan birleşmelerin ve kısmi satışların etkileri, hedef şirketlerin hisse getirileri kullanılarak incelenmiştir. Halka duyurudan bir gün önce başlayan ve bir gün sonra biten üç günlük zaman aralığında, hedef şirket hissedarlarının birleşmelerde yüzde 8,56, kısmi satışlarda ise yüzde 2,25 oranında kümülatif anormal getiri elde ettiği ortaya konmuştur. Birleşmelerde, alıcı, hedef şirketin yönetim haklarını satın almaktadır: alıcı anlaşmadan önce hedef şirket hisselerinin yüzde 50'sinden azına sahipken, anlaşma sayesinde yüzde 50'den fazlasına sahip olmayı amaçlamaktadır. Kısmi satışlar sonucunda ise alıcı ya hedef şirketin azınlık hissedarı konumuna gelmekte ya da halen elinde bulundurduğu çoğunluk hisselerinin oranını yükseltmektedir. Birleşmelerde gözlenen yüksek getiriler, alıcının, hedef şirketin yönetimini ele geçirmek için kısmi satışlara göre daha yüksek bir bedel ödediğini göstermektedir.

Yasal düzenlemelerin kısıtlarının azalması, teknolojik gelişmeler, ve artan rekabet şirketlerin birleşme yoluyla yeniden yapılanmasını tetiklemektedir (Gort, 1969; Mitchell ve Mulherin, 1996; Harford, 2005; Powell ve Yawson, 2005). Bu çalışmanın örneklem dönemi içinde olan 1991 ile 2009 yıllarında Avrupa Birliği'ne uyum için yasal düzenlemeler gerçekleştirilmiştir (Aydınlı ve Waxman, 2001; Öniş ve Bakır, 2007). Gene örneklem kapsamına düşen 1999 ve 2001 yılları arasında ciddi bir ekonomik bunalım yaşanmıştır (Kibritçioğlu, 2001; Alper, 2001; Tanyeri, 2010). Bu gelişmeler, Türk şirketlerini ayakta kalabilmek için birleşmeye zorlamış olabilir.

ABD ve Avrupa birleşmelerini inceleyen çalışmalar, hedef şirket hissedarlarının birleşmelerden daha karlı çıktığını ortaya koymuştur. ABD’de, tamamlanmış birleşmelerde (taraflar arasında nihai anlaşmanın imzalandığı birleşmeler), hedef şirket hissedarlarının, duyurunun yapıldığı günü merkez alan üç günlük zaman aralığında, yüzde 16 ile yüzde 23 
arasında değişen kümülatif anormal getiriler elde ettiği gösterilmiştir (Andrade ve diğerleri, 2001; Mulherin ve Boone, 2000; Bargeron ve diğerleri, 2008; Kuipers ve diğerleri, 2009). Avrupa'da ise kümülatif anormal getiriler yüzde 5 ile yüzde 13 düzeyleri arasında gerçekleşmiştir (Campa ve Hernando, 2004; Georgen ve Renneboog, 2004; Martynova ve Renneboog, 2009). Mandacı (2004) 1998 ile 2003 yıllarını kapsayan çalışmasında, Türkiye’de gerçekleşen on iki birleşmede, hedef şirketin hissedarlarının yüzde 7,21 oranında kümülatif anormal getiri elde ettiğini bulmuştur. Çukur ve Eryiğit (2006) ise 2004 ile 2005 y1lları arasında gerçekleşen beş banka birleşmesinde hedef Türk bankalarının duyuru gününde ortalama yüzde 4,70 oranında anormal getiri elde ettiğini ortaya koymuşlardır ${ }^{1}$.

Bu çalışmada, hedef şirket hissedarlarının, Türkiye'de tamamlanmış birleşmelerde, duyuru günü merkezli üç günlük zaman aralığında, yüzde 8,93 oranında kümülatif anormal getiri elde ettiği ortaya konmuştur. Türkiye'de hedef şirket hissedarların ABD’de elde edilen getirilere kıyasla daha düşük getiri elde ettiği görülmektedir. Bu duruma yol açan başlıca iki etken olduğu düşünülmektedir.

İlk olarak, duyuru tarihini belirlemedeki zorluklar ve olası bilgi sızıntıları, birleşmenin, hisse fiyatı üzerindeki etkisinin, duyuru tarihinden daha önce gerçekleşmesine sebep olabilmektedir. Bu nedenle, duyuru gününde ölçülen anormal getiriler, birleşme etkisinin tamamını yansıtmayabilmektedir. Maletesta ve Thomson (1985) ve Cornett ve diğerleri (2011) piyasanın birleşmeleri duyurudan önce sezmesi (veya duyuru ile ilgili bilgi sızması) durumunda, olay çalışması yönteminin birleşmenin tüm etkisini ölçmede başarısız olduğunu bulmuşlardır. Dolayısıyla, piyasa öngörüleri, bilgi sızıntısı ve hatalı duyuru tarihi, olay çalışması yönteminin güvenirliğini azaltmaktadır. İkinci olarak, ülkeden ülkeye farklılaşan

\footnotetext{
${ }^{1}$ içke (2007) ile Yörük ve Ban (2006) Türk şirket birleşmelerinin hisse fiyatları üzerinde etkilerini inceleyen diğer çalışmalardır.
} 
rekabet ortamı ve yasal düzenlemeler, birleşme sonucu yaratılan değerin alıcı ve hedef şirket hissedarları arasındaki bölüşümünü etkileyebilmektedir.

Bu makale, Türk birleşme ve kısmi satış işlemlerinden oluşan geniş kapsamlı bir örneklemi kullanarak, şirket birleşmeleri literatürüne katkı yapmaya çalışmıştır. Derlenen örneklem 1991 ile 2009 yılları arasında duyurulan ve İstanbul Menkul Kıymetler Borsası'nda kote edilen 125 şirketin birleşme ve kısmi satış işlemini kapsamaktadır.

\section{Araşturma Stratejisi}

\section{A. Yöntem}

$\mathrm{Bu}$ çalışmada olay çalışması yöntemini kullanılmıştır (Brown ve Warner, 1985; MacKinlay, 1997). Anormal getiriler, beklenen getirileri, gerçekleşmiş getirilerden çıkararak hesaplanır. Beklenen getiriler Denklem 1 kullanılarak hesaplanmaktadır. $G_{i, t} i$ hisse senedinin $t$ günündeki getirisini, $G_{m, t}$ ise piyasanın $t$ günündeki getirisini göstermektedir.

$$
G_{i, t}=\alpha_{i}+\beta_{i} G_{m, t}+\varepsilon_{i, t}
$$

Şekil 1 birleşme zaman çizgisini göstermektedir. Olay penceresi duyuru tarihinden 30 gün önce başlamakta, 30 gün sonra ise sona ermektedir. Etkin çalışan hisse senedi piyasalarında, şirket haberleri kamuya açıklandıkları andan itibaren, yatırımcılar alım ve satım işlemleri ile hisse fiyatlarının haberin etkilerini yansıtmasını sağlar ${ }^{2}$. Bu nedenle olay zaman aralığı birleşme veya kısmi satış ile ilgili halka duyuru yapılan ilk günü merkez almaktadır. Tahmin

\footnotetext{
${ }^{2}$ Birleşme ve kısmi satışların etkisinin ölçülebilmesi için Türk hisse senedi piyasasının etkin çalıştı̆̆ı varsayılmaktadır. Balaban ve Kunter (1997), Akdeniz ve diğerleri (2000) ile Özdemir (2008) Türk hisse senedi piyasasının etkinliğini araştırmıştır. Balaban ve Kunter (1997) 1989 ve 1995 yılları verilerini kullanarak piyasasının etkin olmadığı sonucuna varmıştır. Özdemir (2008) ise 1990 ve 2005 yılları verilerini kullanarak Türk piyasasının etkin olduğu sonucuna varmıştır. Akdeniz ve diğerleri (2000) 1992 ve 1998 yılları verilerini kullanarak, Fama-French 3-faktör değerlendirme modelinin (1992), Türk hisselerinin risk ve getiri özelliklerini sermaye varlıkları değerlendirme modeline göre daha iyi açıkladığını bulmuştur.
} 
penceresi olay penceresinden önceki 252 günlük dönemi kapsamaktadır. Beklenen getirilerin hesaplanması için gereken $\alpha$ ve $\beta$ parametreleri regresyon yöntemi ve tahmin penceresi verileri kullanılarak tahmin edilmiştir.

Şekil 1: Birleşme zaman çizgisi

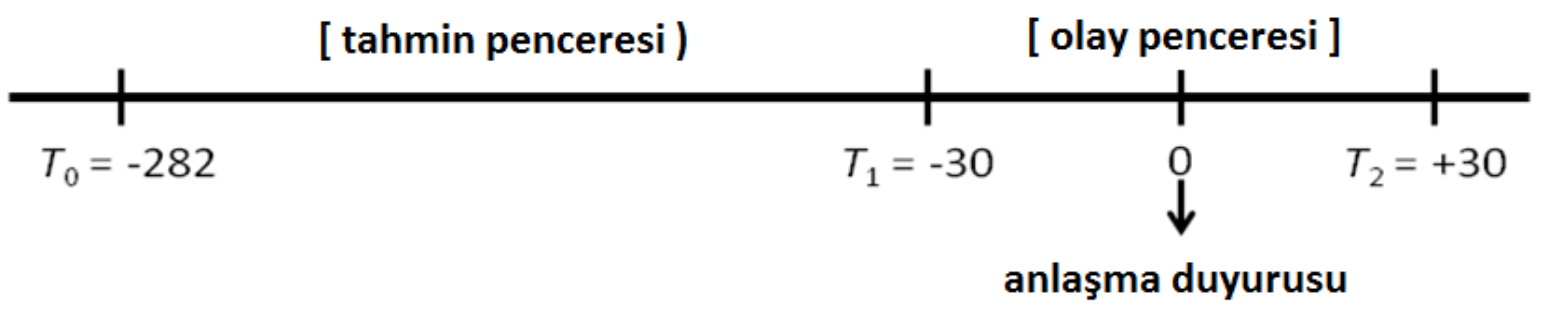

$i$ hisse senedinin $t$ günündeki anormal getirisi $\left(A G_{i, t}\right)$ Denklem 2'de gösterildiği gibi, gerçekleşen getiriden beklenen getirinin çıkartılması ile hesaplanmaktadır. Her şirketin olay penceresindeki günlük anormal getirileri hesaplanmıştır.

$$
A G_{i, t}=G_{i, t}-\left(\hat{\alpha}_{i}+\hat{\beta}_{i} G_{m, t}\right)
$$

Ortalama günlük anormal getiriler, $\bar{A} G_{t}$, ise Denklem 3'teki gibi hesaplanmaktadır. $N_{t}$ veri kümesindeki birleşme sayısını göstermektedir.

$$
\bar{A} G_{t}=\frac{1}{N_{t}} \sum_{i=1}^{N_{t}} A G_{i, t}
$$

Birleşmenin N gün öncesinden, $\mathrm{N}$ gün sonrasına kadar olan ortalama günlük anormal getiriler toplanarak $2 \mathrm{~N}+1$ günlük ortalama kümülatif anormal getiri $\left(K A G_{[-N,+N]}\right)$ hesaplanır (bakınız Denklem 4). 


$$
K A G_{[-N,+N]}=\sum_{t=-N}^{+N} \bar{A} G_{t}
$$

Ortalama günlük anormal getirilerin ve ortalama kümülatif anormal getirilerin sıfırdan farklı olduğunu istatistiksel olarak test etmek için, sırasıyla, Denklem 5 ve Denklem 6'da verilen test istatistikleri kullanılmıştır. Test istatistikleri, ortalama günlük ve kümülatif anormal getirilerin, standart sapmalarının oranına eşittir.

$$
\begin{aligned}
& \bar{A} G_{t} / \hat{S}\left(\bar{A} G_{t}\right) \sim N(0,1) \\
& K A G_{[-N,+N]} /\left(\sum_{t=-N}^{+N} \hat{S}^{2}\left(\bar{A} G_{t}\right)\right)^{\frac{1}{2}} \sim N(0,1)
\end{aligned}
$$

Yukarıdaki istatistiklerde kullanılan $\hat{S}\left(\bar{A} G_{t}\right), \quad \sum_{t=-N}^{+N} \hat{S}^{2}\left(\bar{A} G_{t}\right)$ terimleri aşağıdaki gibi hesaplanmaktadir.

$$
\begin{aligned}
& \hat{S}\left(\bar{A} G_{t}\right)=\sqrt{\left(\sum_{t=T_{0}}^{T_{1}-1}\left(\bar{A} G_{t}-\overline{\bar{A}} G\right)^{2}\right) / T_{1}-T_{0}-1} \\
& \sum_{t=-N}^{+N} \hat{S}^{2}\left(\bar{A} G_{t}\right)=(2 N+1) \hat{S}^{2}\left(\bar{A} G_{t}\right)
\end{aligned}
$$

$T_{0}$ ve $T_{1}$ sırasıyla tahmin penceresi ve olay penceresinin ilk günleridir. $\overline{\bar{A}} G$ ise aşağıdaki gibi hesaplanmaktadir.

$$
\overline{\bar{A}} G=\frac{1}{T_{1}-T_{0}} \sum_{t=T_{0}}^{T_{1}-1} \bar{A} G_{t}
$$




\section{B. Örneklem seçimi}

Örneklem, İMKB'de kote edilen ve bankacılık sektöründe faaliyet göstermeyen şirketleri kapsamaktadır. Securities Data Company (SDC) kullanılarak 02/07/1991 ile 26/01/2006 tarihleri arasında duyurulan 142 birleşme ve kısmi satış işlemi bulunmuştur. Örneklem Dow Jones Factiva, Market Line Financial Deals, ve IMKB şirket haberleri veri tabanları kullanılarak genişletilmiş̧ir. Factiva veri tabanı kullanılarak 17 işlem örnekleme eklenmiş̧ir. Market Line veri tabanından 10, IMKB şirket haberleri veri tabanından ise 3 işlem örnekleme dahil edilmiştir.

Elde edilen 172 şirketin her biri için birden fazla birleşme veya kısmi satış teklifi yapılabilir. Birden fazla teklif alınma durumunda, duyuruların tahmin ve olay pencereleri birbiriyle çakışabilir. Çakışan tahmin ve olay pencerelerinin ortaya çıkaracağı sorunu ortadan kaldırmak için Şekil 2'de gösterilen filtreleme yöntemi uygulanmıştır. Her hangi bir şirketin bir önceki duyurusunu takip eden 312 günlük dönemde duyurulan işlemler örneklemden çıkartılmıştır. Filtreleme soncucu elde edilen nihai örneklem Temmuz 1991 ile Temmuz 2009 arasında duyurulan 125 işlemden oluşmuştur ${ }^{3}$.

\section{Şekil 2: Duyuruların filtrelenmesi}

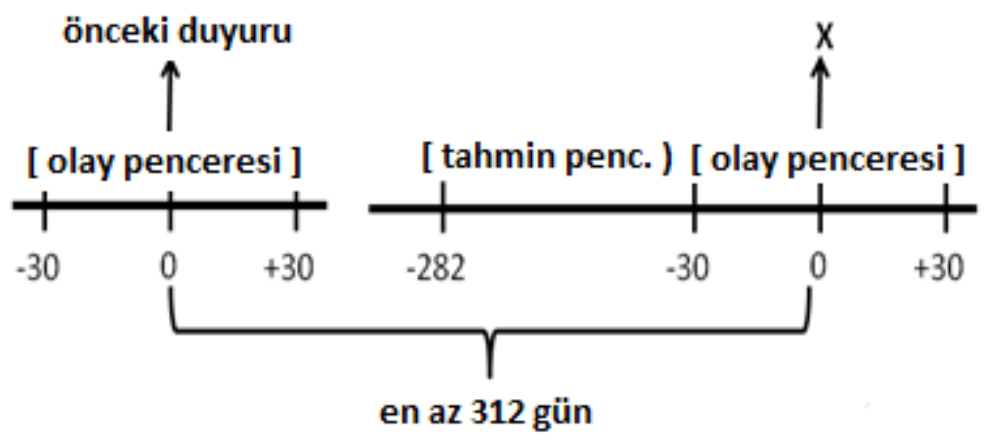

\footnotetext{
${ }^{3}$ SDC veri tabanında belirtilen halka duyuru tarihleri IMKB şirket haberleri veritabanı kullanılarak kontrol edilmiştir. Uyuşmazlık durumunda eldeki en erken tarih duyuru tarihi olarak kullanılmıştır.
} 
Hedef şirketlerin günlük hisse senedi fiyatları ile günlük İMKB-100 endeksi fiyatları Datastream veri tabanından alınmıştır. Hisse getirileri ve endeks getirisi, hisse fiyatlarındaki ve endeksteki günlük yüzdelik değişme hesaplanarak elde edilmiştir.

\section{C. Örneklem istatistikleri}

ABD (Gort, 1969; Mitchell ve Mulherin, 1996; Harford, 2005) ve Avrupa (Powell ve Yawson, 2005) için yapılan çalışmalarda şirket birleşmelerinin hem dönemsel hem de sektörel bazda kümelendiği gözlemlenmektedir. Bu kümelenmeyi yasal düzenlemelerin azalmasına, teknolojik gelişmelere, ve artan rekabete bağlayabiliriz. Türkiye, 1 Ocak 1996 tarihinde Gümrük Birliği'ne katılım konusunda Avrupa Birliği (AB) ile anlaşmaya varmıştır. 17 Aralık 2004 tarihinde ise AB, Türkiye ile tam üyelik müzakerelerine başlanacağını açıklamıştır (Öniş ve Bakır, 2007). Ayrıca, 1999 ile 2001 yılları Türkiye’nin ağır bir ekonomik bunalımdan geçtiği yıllar olarak kayıtlara geçmiştir (Kibritçioğlu, 2001). AB ile gelişen ilişkiler ve 2001'de yaşanan finansal kriz Türkiye'deki rekabet ortamını ve yasal düzenlemeleri önemli ölçüde etkilemiştir ${ }^{4}$. Bu gelişmelere bağlı olarak, örneklem dönemini beş alt dönem halinde incelemek uygun görülmüş ve alt dönemler 1991-1995, 1996-1998, 1999-2001, 2002-2004, ve 2005-2009 olarak belirlenmiştir.

Tablo 1 örneklemin sektörel ve dönemsel bazda dağılımını göstermektedir. Hedef şirketlerin sektörleri 1-haneli “Standard Industrial Classification” (SIC) ${ }^{5}$ düzeyinde tanımlanmıştır. Birleşmelerin ve kısmi satışların en yoğun olduğu dönem, tam üyelik müzakerelerinin

\footnotetext{
${ }^{4}$ Öniş ve Bakır (2007), Bakır ve Öniş (2010) AB ilişkileri ve finansal krizin düzenleyici kurumlar üzerindeki etkilerine; Tanyeri (2010) ise finansal krizin bankacılık sektörü üzerindeki etkilerine değinmişlerdir.

${ }^{5}$ Standard Industrial Classification sistemi şirketleri çalıştıkları sektöre göre sınıflandırmaktadır. USA Department of Labor internet sitesi (bakınız http://www.osha.gov/pls/imis/sicsearch.html) sınıflandırma ile ilgili ayrıntılı bilgi içermektedir.
} 
başlangıcını takip eden 2005-2009 dönemidir. Sektörel bazda ise en yüksek yoğunluk “kimyasal, petrol, kömür, ve kauçuk ürünleri” sektöründe gözlemlenmiştir.

\section{Tablo 1: Anlaşmaların dönemsel ve sektörel dağılımı}

Anlaşmalar, hedef şirketin sektörüne ve duyuru tarihine göre sınıflandırılmıştır. Hedef şirketlerin sektörleri 1haneli SIC düzeyinde tanımlanmıştır.

\begin{tabular}{|l|rrrrrr|r|}
\hline & $\begin{array}{r}\text { 1991- } \\
\text { 1995- }\end{array}$ & $\mathbf{1 9 9 8}$ & $\mathbf{2 0 0 1}$ & $\mathbf{2 0 0 4}$ & $\mathbf{2 0 0 9}$ & \multicolumn{1}{c|}{$\begin{array}{c}\text { Soplam } \\
\text { Sayı }\end{array}$} \\
\hline Kimyasal, Petrol, Kömür, Kauçuk & 8 & 7 & 10 & 5 & 9 & 39 \\
Ürünler & 1 & 5 & 3 & 2 & 5 & 16 \\
Gıda Ürünleri & 6 & 1 & 1 & 2 & 4 & 14 \\
Makine ve Teçhizat & 1 & 4 & 4 & 1 & 3 & 13 \\
Kağıt Ürünleri ve Yayıncılık & 1 & 1 & 3 & 4 & 4 & 13 \\
Toptan ve Perakende Ticaret & 3 & 1 & 3 & 2 & 3 & 12 \\
Ulaşım & 1 & 2 & 0 & 0 & 5 & 8 \\
Metal Endüstrisi ve Ürünleri & 0 & 0 & 2 & 0 & 2 & 4 \\
Madencilik & 0 & 0 & 1 & 0 & 2 & 3 \\
Hizmet & 1 & 0 & 0 & 0 & 2 & 3 \\
Tekstil & 22 & 21 & 27 & 16 & 39 & 125 \\
\hline Toplam Sayı & & & & &
\end{tabular}

Tablo 2 hedef ve alıcı şirket ile anlaşma özelliklerini resmetmektedir. Panel A anlaşma ile ilgili bilgileri özetlemektedir. Örneklemin yüzde 42'sinde alıcı, anlaşmadan önce, hedef şirket hisselerinin yüzde 50'sinden azına sahipken, anlaşma sayesinde yüzde 50'den fazlasına satın almayı amaçlamaktadır. Örneklemin yüzde 66'sında taraflar pazarlıkları başarıyla tamamlamış ve nihai anlaşmaya varmışlardır. Örneklemin yüzde 39'unda alıcı ve hedef firmalar aynı sektörde faaliyet göstermektedir. Alıcı şirketler hedef şirketlere anlaşma bedeli olarak ortalama 729 milyon TL ödemişlerdir. Panel B ve C hedef ve alıcı şirket özelliklerini özetlemektedir. Alıcı şirketlerin yüzde 45'i Türk ve yüzde 25’i halka açık şirketlerdir. Hedef 
şirketler duyurudan bir yıl önce ortalama 573 milyon \$ değerindeki varlıklarını kullanarak 813 milyon \$ satış yapmış ve bu satışlardan 46 milyon \$ kar etmişlerdir.

\title{
Tablo 2 - Tanımlayıcı istatistikler
}

\begin{abstract}
Anlaşma, satın alan ve alınan şirket özellikleri SDC veritabanı verileri kullanılarak örneklem için özetlenmiştir. Panel A anlaşma ile ilgili bilgileri beş kalem altında özetlemektedir. (i) Birleşme: Alıcı şirket anlaşmadan önce hedef şirket hisselerinin yüzde 50'sinden azına sahipken, anlaşma sayesinde yüzde 50'den fazlasına sahip olmayı amaçlamaktadır. Kısmi satış: Alıcı ya hedef şirketin azınlık hissedarı konumuna gelmekte ya da halihazırda elinde bulundurduğu çoğunluk hisselerinin oranını yükseltmektedir. (ii) Tamamlanmış anlaşma: Tarafların pazarlıkları başarıyla tamamladığı ve nihai anlaşmaya vardığı anlaşmalardır. (iii) Aynı sektör: Alıcı ve hedef firmalar aynı sektörde faaliyet göstermektedir (iki haneli SIC kodlarına göre). (iv) Anlaşma çerçevesinde satın alınması planlanan hisse senedi oranının örneklem için ortalaması verilmektedir. (v) Örneklem için ortalama, medyan ve toplam anlaşma değeri (2009 y1lı tabanlı ve milyon TL cinsinden) verilmektedir. Panel B satın alan şirket uyruğunu ve sermaye yapısını özetlemektedir. Panel C hedef şirketin önemli bilanço ve gelir tablosu kalemlerini satış duyurusundan önceki bir yıllık dönem için özetlemektedir.
\end{abstract}

\begin{tabular}{|c|c|}
\hline \multicolumn{2}{|l|}{ Tanımlayıcı İstatistikler } \\
\hline \multicolumn{2}{|c|}{ Panel A - Anlaşma Özellikleri (Tüm Örneklem, $N=125$ ) } \\
\hline \multicolumn{2}{|c|}{ Anlaşma tipi (\%) } \\
\hline Birleşme / Kısmi satış & $42 / 58$ \\
\hline \multicolumn{2}{|l|}{ Anlaşma sonucu (\%) } \\
\hline Tamamlanmış / Tamamlanmamış & $66 / 34$ \\
\hline \multicolumn{2}{|l|}{ Anlaşmadaki taraf şirketlerin sektörleri (\%) } \\
\hline Aynı sektör / Aynı sektör değil & $39 / 61$ \\
\hline Satın alınan ortalama hisse payı $(\%)(\mathrm{N}=111)$ & 40 \\
\hline \multicolumn{2}{|l|}{ Anlaşma değeri (milyon TL, 2009 tabanlı) $(\mathrm{N}=85)$} \\
\hline Ortalama & 729 \\
\hline Medyan & 150 \\
\hline Toplam & 61.955 \\
\hline \multicolumn{2}{|c|}{ Panel B - Satın Alan Şirketin Özellikleri (N=125) } \\
\hline \multicolumn{2}{|c|}{ Uyruğu (\%) } \\
\hline Türk / Yabancu / Bilinmiyor & $45 / 42 / 13$ \\
\hline \multicolumn{2}{|l|}{ Sermaye yapısı (\%) } \\
\hline Halka açık / Halka açık değil / Bilinmiyor & $25 / 54 / 21$ \\
\hline \multicolumn{2}{|c|}{ Panel C - Hedef Şirket Özellikleri $(\mathrm{N}=58)$} \\
\hline Satış (ortalama, milyon \$) & 813 \\
\hline Faiz ve vergi öncesi kar (ortalama, milyon \$) & 55 \\
\hline Net kar (ortalama, milyon \$) & 46 \\
\hline Toplam varlıklar (ortalama, milyon \$) & 573 \\
\hline Özkaynak (ortalama, milyon \$) & 301 \\
\hline
\end{tabular}




\section{Bulgular}

\section{A. Günlük anormal getiriler}

Ortalama günlük anormal getiriler Denklem 3’te gösterildiği gibi hesaplanmıştır. Tablo 2 duyuru gününden yedi gün önce başlayan ve yedi gün sonra biten zaman aralığında hesaplanan günlük ortalama anormal getirileri sunmaktadır.

Duyurudan önceki gün, duyuru günü, ve duyurudan sonraki gün, satın alınan şirket hissedarları sırasıyla yüzde 1,22, 2,04, ve 1,62 oranlarında anormal getiri elde etmişlerdir. Bu getiriler istatistiksel olarak anlamlıdır.

\section{Tablo 3: Günlük anormal getirler}

Duyuru günü, olay günü 0 olarak belirlenmiştir. Duyuru gününden yedi gün önce ve yedi gün sonrasını kapsayan on-beş gün için anormal getirilerin ortalamsı yüzdelik olarak (i) tüm örneklem, (ii) birleşme ve kısmi satış alt kümeleri, (iii) tamamlanmış ve tamamlanmamış anlaşma alt kümeleri, (iv) tamamlanmış birleşme alt kümesi için verilmiştir. Denklem 5'te verilen test istatistiği ile getirilerin anlamlılığ ölçülmüştür. ***,**, ve * sırasıyla yüzde 1,5 , ve 10 düzeylerindeki istatistiksel anlamlılı̆̆ ifade etmektedir.

\begin{tabular}{|c|c|c|c|c|c|c|}
\hline \multirow{2}{*}{$\begin{array}{l}\text { Olay } \\
\text { günü }\end{array}$} & \multirow{2}{*}{$\begin{array}{c}\text { Tüm } \\
\text { örneklem } \\
(\mathrm{N}=125)\end{array}$} & \multirow{2}{*}{$\begin{array}{c}\text { Birleşme } \\
(\mathrm{N}=52)\end{array}$} & \multirow{2}{*}{$\begin{array}{c}\text { Kismi } \\
\text { satış } \\
(\mathrm{N}=73)\end{array}$} & \multicolumn{2}{|c|}{ Tamamlanmış } & \multirow{2}{*}{$\begin{array}{c}\text { Tamamlanmış } \\
\text { birleşme } \\
(\mathbf{N}=42)\end{array}$} \\
\hline & & & & $\begin{array}{c}\text { Evet } \\
(\mathrm{N}=83)\end{array}$ & $\begin{array}{c}\text { Hayır } \\
(\mathrm{N}=42)\end{array}$ & \\
\hline-7 & $-0,25$ & 0,16 & $-0,54$ & $-0,07$ & $-0,59$ & 0,11 \\
\hline-6 & 0,21 & 0,73 & $-0,17$ & 0,52 & $-0,42$ & 0,83 \\
\hline-5 & $0,67 *$ & 0,73 & 0,62 & $0,91 * *$ & 0,17 & 0,58 \\
\hline-4 & 0,3 & 0,05 & 0,48 & 0,68 & $-0,45$ & 0,36 \\
\hline-3 & 0,27 & 0,48 & 0,11 & 0,19 & 0,41 & 0,33 \\
\hline-2 & 0,42 & $1,04 * *$ & $-0,02$ & $0,84^{*}$ & $-0,4$ & $1,41^{* *}$ \\
\hline-1 & $1,22 * * *$ & $2,87 * * *$ & 0,05 & $1,77 * * *$ & 0,13 & $3,31 * * *$ \\
\hline 0 & $2,04 * * *$ & $2,87 * * *$ & $1,44^{* * *}$ & $2,52 * * *$ & $1,09 *$ & $3,09 * * *$ \\
\hline 1 & $1,62 * * *$ & $2,82 * * *$ & 0,76 & $1,79 * * *$ & $1,28 * *$ & $2,53 * * *$ \\
\hline 2 & $0,81^{* *}$ & 0,26 & $1,21 * *$ & $0,88 * *$ & 0,68 & 0,23 \\
\hline 3 & $-0,43$ & $-0,18$ & $-0,62$ & $-0,34$ & $-0,62$ & 0,06 \\
\hline 4 & $-0,87 * *$ & $-1,46 * * *$ & $-0,45$ & $-0,99 * *$ & $-0,63$ & $-1,18 * *$ \\
\hline 5 & $-0,41$ & 0,33 & $-0,93 *$ & $-0,26$ & $-0,69$ & 0,15 \\
\hline 6 & $-0,29$ & $-0,37$ & $-0,23$ & $-0,87 * *$ & 0,86 & $-0,88$ \\
\hline 7 & $-0,01$ & 0,04 & $-0,05$ & $-0,25$ & 0,45 & $-0,67$ \\
\hline
\end{tabular}


Duyurudan önceki gün, duyuru günü, ve duyurudan sonraki günde hesaplanan ortalama anormal getirilerin, birleşmelerde, kısmi satışlara göre daha yüksek olduğu ortaya konmuştur. Yönetimin el değiştirmesine yol açan işlemlerde görülen yüksek getiriler: (i) çoğunluk hissedarı olmanın avantajları (Jensen ve Meckling, 1976; Fama ve Jensen, 1983) ve (ii) yatırım faaliyetlerinin daha etkin bir yönetime devredilmesi (Holmes ve Schmitz, 1995; Fescioğlu-Ünver ve Tanyeri, 2011) ile açıklanabilir. Bu bulguya paralel olarak Hite ve diğerlerinin (1987) ABD için yaptığı bir çalışmada yönetim haklarının el değiştirdiği işlemlerde, satın alınan şirket hissedarlarının kısmi satışlara göre daha yüksek anormal getiriler elde ettiğini bulmuşlardır.

Tamamlanmış işlemlerde duyuru günü etrafinda elde edilen anormal getirilerin, tamamlanmamış işlemlerdeki getirilerden daha yüksek olduğu bulunmuştur. Bu bulguya göre piyasa, bir teklifin başarıyla tamamlanıp tamamlanmayacağını teklifin duyurulduğu günlerde tahmin edebilmektedir. Asquith (1983) ve Martynova ve Renneboog (2009) bu çalışmada bulunan sonuçları sırasıyla ABD’de ve Avrupa’daki şirketler için ortaya koymuşlardır. Son olarak, örneklemin sadece yüzde 34’ünde birleşme görüşmeleri başarıyla tamamlanmıştır. Bu işlemlerde, satın alınan şirketler, duyuru gününden iki ile bir gün önce, duyuru gününde, ve duyuru gününden bir gün sonra, pozitif ve anlamlı anormal getiriler elde etmiştir.

\section{B. Kümülatif anormal getiriler}

Günlük ortalama anormal getiriler 3 günlük, 7 günlük, ve 11 günlük dönemlerde toplanarak ortalama kümülatif anormal getiriler hesaplanmıştır (bakınız Denklem 4). Hesaplama sonuçları Tablo 3’te tüm örneklem ve ilgili alt kümeler için sunulmaktadır. Hedef şirket hissedarları 3 günlük, 7 günlük, ve 11 günlük dönemlerde sırasıyla yüzde 4,88, 5,94, ve 5,63 oranlarında kümülatif anormal getiri elde etmiştir. Önceki bölümde elde ettiğimiz bulgulara paralel olarak, yönetimin el değiştirmesi ve işlemin başarı ile sonuçlandırılması elde edilen 
kümülatif getirilerin daha yüksek olmasına yol açmaktadır. Söz konusu alt kümelerde elde edilen getiriler arasındaki farkların istatistiksel olarak anlamlı olduğu Tablo 3'te görülmektedir. En yüksek kümülatif anormal getiriler, tamamlanmış birleşmeler alt kümesinde bulunmuştur.

\section{Tablo 4: Kümülatif anormal getiriler}

3-, 7-, ve 11-günlük kümülatif anormal getirilerin ortalaması yüzdelik olarak (i) tüm örneklem, (ii) birleşme ve kısmi satış alt kümeleri, (iii) tamamlanmış ve tamamlanmamış işlem alt kümeleri, (iv) tamamlanmış birleşme alt kümesi için verilmiştir. Denklem 6'da verilen test istatistiği ile getirilerin anlamlılığı ölçülmüştür. ***,**, ve * sırasıyla yüzde 1, 5, ve 10 düzeylerindeki istatistiksel anlamlılığı ifade etmektedir.

\begin{tabular}{|l|ccc|c|}
\hline & $\begin{array}{c}3 \text { günlük } \\
{[-1,+1]}\end{array}$ & $\begin{array}{r}\text { günlük } \\
{[-3,+3]}\end{array}$ & $\begin{array}{c}11 \text { günlük } \\
{[-5,+5]}\end{array}$ & İşlem sayısı \\
\hline Tüm örneklem & $4,88^{* * *}$ & $5,94^{* * *}$ & $5,63^{* * *}$ & 125 \\
Birleşme & & & & \\
Evet & $8,56^{* * *}$ & $10,17^{* * *}$ & $9,82^{* * *}$ & 52 \\
Hayır & $2,25^{* * *}$ & $2,93^{* *}$ & $2,65^{*}$ & 73 \\
Fark & $6,31^{* * *}$ & $7,24^{* * *}$ & $7,17^{* *}$ & \\
Tamamlanmış işlemler & & & & \\
Evet & $6,08^{* * *}$ & $7,65^{* * *}$ & $8,00^{* * *}$ & 83 \\
Hayır & $2,5^{* *}$ & 2,56 & 0,97 & 42 \\
Fark & $3,58^{*}$ & $5,09^{* *}$ & $7,03^{* *}$ & \\
Tamamlanmış birleşme & & & & \\
Evet & $8,93^{* * *}$ & $10,96^{* * *}$ & $10,87^{* * *}$ & 42 \\
Hayır & $2,83^{* * *}$ & $3,4^{* * *}$ & $2,99^{* *}$ & 83 \\
Fark & $6,1^{* * *}$ & $7,56^{* *}$ & $7,88^{* *}$ & \\
\hline
\end{tabular}

Şirket birleşmeleri ve kısmı satışlar, yasal düzenlemelerin değiştiği dönem ve sektörlerde, farklı sonuçlara yol açabilir ${ }^{6}$. Bu nedenle, örneklem dönem ve sektör alt kümelerine bölünmüştür. Tablo 5 Panel A, örneklemi 2001 öncesi ve sonrası alt kümelerine ayırmış ve Panel B, örneklemi hedef şirketin sektörüne göre yedi alt kümeye ayırmıştır. Panel A'da

\footnotetext{
${ }^{6}$ Campa ve Hernando (2004) yasal düzenlemelerin yoğun olduğu sektörlerde çalışan şirketlerin birleşmelerinde ölçülen anormal getirilerin diğer şirket birleşmelerine göre daha düşük olduğunu göstermiştir.
} 
görüldüğü üzere, 2001 öncesi ve sonrası hesaplanan 3-günlük kümülatif anormal getirilerde istatistiksel olarak anlamlı bir değişim gözlenmemektedir. Panel B'de görüldüğü üzere, kümülatif anormal getirilerde sektörel bazda farklıklıklar gözlenmekte ama alt kümelerdeki veri kıtlağı nedeni ile farklıklık istatistiksel olarak anlamlı bulunmamaktadır ${ }^{7}$.

Tablo 5: 3-günlük kümülatif anormal getirilerde dönemsel ve sektörel farklar

3-günlük kümülatif anormal getirilerin ortalaması, medyanı ve standart sapması yüzdelik olarak (i) 2001 öncesi ve sonrası alt kümeleri, (ii) yedi sektör alt kümesi için verilmiştir. Sektörler belirlenirken tek haneli SIC kodları baz alınmıştır. Sanayi sektöründeki bazı alt sektörlere ait anlaşmaların fazlalığı sebebiyle ilgili alt sektörler için iki haneli SIC kodları kullanılmıştır.

\begin{tabular}{|c|c|c|c|c|}
\hline & Sayt & Ortalama & Medyan & Standart Sapma \\
\hline \multicolumn{5}{|l|}{ Panel A - Yıllara göre değişim } \\
\hline 2001 öncesi (I) & 55 & $5.10 \%$ & $3.77 \%$ & $10.03 \%$ \\
\hline 2001 sonrasi (II) & 70 & $4.70 \%$ & $\begin{array}{c}1.83 \% \\
\text { t-test }\end{array}$ & $10.68 \%$ \\
\hline Fark (I) - (II) & & $0.40 \%$ & 0.22 & \\
\hline \multicolumn{5}{|l|}{ Panel B - Sektörlere göre değişim } \\
\hline Ulaşım, iletişim, elektrik ve gaz & 12 & $3.25 \%$ & $2.02 \%$ & $11.03 \%$ \\
\hline $\begin{array}{l}\text { Perakende ve toptan ticaret } \\
\text { Sanayi }\end{array}$ & 13 & $3.29 \%$ & $5.57 \%$ & $8.66 \%$ \\
\hline 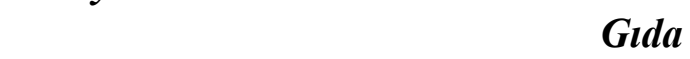 & 16 & $6.12 \%$ & $0.19 \%$ & $14.04 \%$ \\
\hline Petrol & 13 & $5.94 \%$ & $5.34 \%$ & $10.13 \%$ \\
\hline Taş, kil ve cam & 15 & $4.37 \%$ & $1.01 \%$ & $8.86 \%$ \\
\hline Diğer (Sanayi) & 49 & $5.12 \%$ & $3.13 \%$ & $9.77 \%$ \\
\hline Diğger sektörler & 7 & $6.47 \%$ & $5.97 \%$ & $13.17 \%$ \\
\hline
\end{tabular}

\section{Sonuç}

Bu çalışmada, 1991 ile 2009 yılları arasında halka duyurulan birleşmelerin ve kısmi satışların hedef şirketlerin hisse fiyatları üzerindeki etkileri incelenmiştir. Başarı ile sonuçlandırılan birleşmelerde, satın alınan şirket hissedarlarının, duyuru gününden bir gün önce başlayan ve bir gün sonra biten zaman aralığında, yüzde 8,93 oranında kümülatif anormal getiri elde ettiği

7 Çoklu regresyon yöntemi kullanılarak alııının uyruğu, alıcı ve satıcının aynı sektörde olması, ve anlaşma büyüklüğü gibi unsurların, kümülatif anormal getiriyi etkileyip etkilemediği araştırılmıştır. Alıcının uyruğu, alıcı ve satıcının aynı sektörde olması, ve anlaşma büyüklügü kümülatif anormal getiriyi (bu örneklemde) etkilememektedir. 
bulunmuştur. Bu getirinin, ABD’deki (yüzde 20 civarı) ve Avrupa'daki (yüzde 10 civarı) hissedarlarının elde ettiği getirilere kıyasla daha düşük olduğu gözlemlenmiştir. Bu durumun çeşitli nedenleri olabilir. Birinci olarak, duyuru tarihleri teker teker kontrol edilmiş olsa da piyasa haberi gazetelerden önce almış olabilir. İkinci olarak, şirketlerden sızan bilgiler nedeni ile anormal getiriler, birleşmenin tam etkisini temsil etmeyebilmektedir. Ayrıca piyasa bilgi sızıntısı olmadan da birleşen şirketleri duyuru öncesinde öngörebilmektedir. Üçüncü olarak, ülkeler arasında farklılık gösteren yasal düzenlemeler ve rekabet ortamı birleşmenin yarattığı değerin hedef ve alıcı hissedarlar arasındaki dağılımın etkileyebilmektedir. 


\section{Kaynakça}

Akdeniz L., Aydoğan, K. ve Altay-Salih, A. (2000) “A cross-section of expected stock returns on the Istanbul Stock Exchange," Russian and East European Finance and Trade, 36, 626.

Alper, C. E. (2001) “The Turkish liquidity crisis of 2000: what went wrong,” Russian and East European Finance and Trade, 37, 58-80.

Andrade, G., Mitchell, M. ve Stafford, E. (2001) "New evidence and perspectives on mergers,” The Journal of Economic Perspectives, 15, 103-120.

Asquith, P. (1983) “Merger bids, uncertainty, and stockholder returns,” Journal of Financial Economics, 11, 51-83.

Aydınl1, E. ve Waxman, D. (2001) “A dream become nightmare? Turkey's entry into European Union,” Current History, 100, 381-388.

Bakır, C. ve Öniş, Z. (2010) "The Emergence and the Limits of the Regulatory State: The Political Economy of Turkish Banking Reforms in the Age of Post-Washington Consensus," Development and Change, 41:1, 77-106.

Balaban, E., and Kunter, K., (1997) "A note on the efficiency of financial markets in a developing country,” Applied Economics Letters, 4, 109-112.

Bargeron, L. L., Schlingemann, F. P., Stulz, R. M. ve Zutter, C. J. (2008) "Why do private acquirers pay so little compared to public acquirers," Journal of Financial Economics, 89, 375-390.

Brown, S. J. ve Warner, J. B. (1985) "Using daily stock returns,” Journal of Financial Economics, 14, 3-31.

Campa, J. M. ve Hernando, I. (2004) "Shareholder value creation in European M\&As," European Financial Management, 10, 47-81.

Cornett, M.C., Tanyeri, B. ve Tehranian, H. (2011) "The Effect of Merger Anticipation on Bidder and Target Firm Announcement Period Returns” Journal of Corporate Finance, 17:3, 595-611.

Çukur, S. ve Eryiğit, R. (2006) "Banka birleşme ve devralma olaylarının borsadaki etkisi," Iktisat Issletme ve Finans, 21, 96-107.

Fama, E. F. ve French, R. K. (1992) “The cross-section of expected stock returns,” Journal of Finance, 47, 427-465.

Fama, E. F. ve Jensen, M. C. (1983) “Separation of ownership and control,” Journal of Law and Economics, 26, 301-325. 
Fescioğlu-Ünver, N. ve Tanyeri, B. (2011) “A comparison of artificial neural network and multinomial logit models in predicting mergers”, Bilkent Üniversitesi Çalışma Makalesi.

Goergen, M. ve Renneboog, L. (2004) "Shareholder wealth effects of European domestic and cross-border takeover bids,” European Financial Management, 10, 9-45.

Gort, M. (1969) “An economic disturbance theory of mergers,” The Quarterly Journal of Economics, 83, 624-642.

Harford, J. (2005) "What drives merger waves?,” Journal of Financial Economics, 77, 529560.

Hite, G. L., Owers, J. E. ve Rogers, R. C. (1987) “The market for interfirm asset sales: partial sell-offs and total liquidations,” Journal of Financial Economics, 18, 229-252.

Holmes, T. J. ve Schmitz, J. A. (1995) "On the turnover of business firms and business managers,” Journal of Political Economy, 103, 1005-1038.

İçke, B. T. (2007) Şirket Birleşmeleri Hisse Senedi Değeri ve Finans Sektörü. İstanbul, Türkiye: Derin Yayıncılık.

Jensen, M. C. ve Meckling, W. H. (1976) "Theory of the firm: managerial behavior, agency costs, and ownership structure,” Journal of Financial Economics, 3, 305-360.

Kibritçioğlu, A. (2001) “Türkiye’de ekonomik krizler ve hükümetler, 1969-2001,” Yeni Türkiye Dergisi, 1, 174-182.

Kuipers, D. R., Miller, D. ve Patel, A. (2009) "The legal environment and corporate valuation: evidence from cross-border takeovers," International Review of Economics \& Finance, 18, 552-567.

MacKinlay, A. C. (1997) "Event studies in economics and finance," Journal of Economic Literature, 35, 13-39.

Malatesta, P., ve Thomson, R. (1985) "Partially anticipated events," Journal of Financial Economics, 14, 237-250.

Mandacı, P. E. (2004) "Şirketlerin birleşme ve satın alma duyurularının hisse senedi fiyatları üzerine etkileri,” Íktisat Işletme ve Finans, 19, 118-124.

Martynova, M. ve Renneboog, L. (2011) “The performance of the European market for corporate control: evidence from the $5^{\text {th }}$ takeover wave," European Financial Management, 17, 208-259.

Mitchell, M. L. ve Mulherin, J. H. (1996) “The impact of industry shocks on takeover and restructuring activity,” Journal of Financial Economics, 41, 193-229. 
Mulherin, J. H. ve Boone, A. L. (2000) “Comparing acquisitions and divestitures,” Journal of Corporate Finance, 6, 117-139.

Öniş, Z. ve Bakır, C. (2007) “Turkey’s political economy in the age of financial globalization: the significance of the EU anchor,” South European Society \& Politics, 12, 147-164.

Özdemir, Z. A. (2008) "Efficient market hypothesis: evidence from a small open-economy," Applied Economics 40, 633-641.

Powell, R. ve Yawson, A. (2005) "Industry aspects of takeovers and divestitures: evidence from the UK,” Journal of Banking \& Finance, 29, 3015-3040.

Tanyeri, B. (2010) "Financial transparency and sources of hidden capital in Turkish banks," Journal of Financial Services Research, 37, 25-43.

Yörük, N. ve Ban, Ü. (2006) "Şirket birleşmelerinin hisse senedi fiyatlarına etkisi: İMKB'de işlem gören gıda sektörü şirketlerinde birleşme etkisinin analizi,” Muhasebe ve Finansman Dergisi, 40, 88-101. 